\title{
АНАЛІЗ НАВЧАЛЬНОГО ПЛАНУ ПІДГОТОВКИ ЗДОБУВАЧІВ ВИЩОЇ ОСВІТИ ДРУГОГО (МАГІСТЕРСЬКОГО) РІВНЯ ГУМАНІТАРНОГО НАПРЯМКУ
}

Theory and Practice. Pedagogical science, Vol. 3-4 (4849), pp. 59-65.[in Ukrainian].

4. Piddyachyy, M. (2017). "Osvita i nauka Ukrayiny sotsialno-trudovyy rozvytok molodi"["Education and science of Ukraine: the social and labor development of youth"]. Scientific journal of the National Pedagogical University named after M.P. Drahomanov. Series 13: Problems of Labor and Vocational Training. Vol. 8, pp. 75-80. [in Ukrainian].

5. Tarara, A. M. (2016). Metodolohichni aspekty proektuvannia zmistu profilnoho navchannia tekhnolohii u starshii shkoli [The Methodological aspects of designing the content of profile education of technology in high school]. The problems of the modern textbook: a collection of 217 scientific works. (Ed.). O. M. Topuzov. Kyiv: Pedahohichna dumka, Vol. 16, pp. 403 - 414. [in Ukrainian].

6. Tutashynskyy, V.I. \& Kiryutchenkova, I.V. (2018). Tekhnolohiyi. 10 (11) kl. [Technologies. 10 (11) cl.]. Kyiv: Pedahohichna dumka, 228 p. [in Ukrainian].

7. Assanov, M. O., Vaskivskyy, M. V., Dorotyuk, V. I. et al. (2013). Formuvannya osvitnoho seredovyshcha profilnoyi shkoly: Monohrafiya [The formation of the educational environment of the profile school: a monograph]. Kyiv: Pedahohichna dumka, 200 p. [in Ukrainian].

Стаття надійшла до редакції 08.02.2019

УДК [378.091.214:8]:005.52

DOI:

Сергій Шаров, кандидат педагогічних наук, доиент кафедри української $і$ зарубіжної літератури

Мелітопольського державного педагогічного університету імені Богдана Хмельницького

\section{АНАЛІЗ НАВЧАЛЬНОГО ПЛАНУ ПДГОТОВКИ ЗДОБУВАЧІВ ВИЩОЇ ОСВІТИ ДРУГОГО (МАГІСТЕРСЬКОГО) РІВНЯ ГУМАНІТАРНОГО НАПРЯМКУ}

У статті аналізується навчальний план підготовки здобувачів вищої освіти другого (магістерського) рівня спеціальності 014.01 Середня освіта. Украӥнська мова і література. Навчання магістрів передбачає иілеспрямований та багатофункиіональний проиес, який має специфічну мету, форми та методи. Визначено дисципліни, які відносяться до ичиклів загальної, професійної підготовки, а також ичклувибіркових дисциплін. Розглянуто перелік загальних та фахових компетентностей, проаналізовано результати навчання, які свідчать про ступінь сформованості компетентностей у межах обраної спеціальності.

Ключові слова: здобувач вищої освіти; підготовка магістрів; украӥнська мова і література; вища школа; навчальний план; освітня програма.

Jim. 11.

Serhiy Sharov, Ph.D.(Pedagogy), Associate Professor of the Ukrainian and Foreign Literature Department Melitopol Bohdan Khmelnytskiy State Pedagogical University

\section{ANANALYSIS OFTHE CURRICULUM FOR THE PREPARATION OF CANDIDATES FOR HIGHER EDUCATION OFTHE SECOND (MASTER'S) LEVEL OFTHE HUMANITIES}

The article focuses on the analysis of the curriculum for the preparation of candidates for higher education of the second (master) level of specialty 014.01 Secondary education. Ukrainian language and literature. The applicants can enter the second (master) level on the basis of the educational degree "Bachelor" or the educational qualification level "Specialist". Master training provides for a focused and multifunctional process of preparing competitive specialists who have a specific goal, forms and methods. The main forms of organization of education for applicants of higher education of the second (master's) level include lectures, practical, seminar classes, independent educational activities of students. One of the ways to modernize the content of education with a competence-based approach is to update the educational programs and curricula for the preparation of a competitive applicant for higher education. It is noted that the preparation of masters is based on several regulatory documents of the specialty, namely the educational profile of the specialty, the educational program of the specialty, the curriculum of the specialty. It is noted that applicants for higher education of the second (master) level of this specialty are studying according to the educational and professional program, which is called "Secondary education. Ukrainian language and literature. English language and literature, fields of knowledge 01 Education / Pedagogy". It is revealed that in the curriculum there are disciplines related to the cycles of general professional training, as well as cycles of selective disciplines. The process of training in the magistracy should be aimed at the formation of students " general cultural and professional competencies, provided for by the educational standards. The article describes the competencies that a student acquires during studying at the magistracy. It is noted that the educational program contains only one integral competence, but a significant number of general and professional competencies that are 
formed during the course of graduate studies. Analyzed learning outcomes indicate the degree of formation of competences in the chosen specialty.

Keywords: an applicant of higher education; preparation of masters; Ukrainian language and literature; a higher school; curriculum; an educational program.

$\Pi$ остановка проблеми. Сьогоденні вимоги щодо процесу модернізації змісту вищої освіти в першу чергу стосуються впровадження компетентнісного підходу у навчальний процес, врахування стандартів і рекомендацій європейського простору вищої освіти, забезпечення студентської мобільності тапідвищення конкурентоспроможності майбутнього фахівця. У межах розвитку проекту Тюнінг та сучасних викликів 3 боку суспільства відбувається процес розробки освітніх програм та навчальних планів підготовки здобувачів освіти різних рівнів. Особливої уваги набуває питання підготовки магістрів гуманітарного напрямку, зокрема майбутніх учителів української мови i літератури, оскільки вони забезпечують процес виховання та навчання молоді, яка приймає участь у розбудові нашої держави та їі активному розвитку. Від того, які компетентності будуть сформовані та розвинугі уздобувачів вищої освіти, залежить їх конкурентоспроможність, здатність принести користь суспільству та державі.

Аналіз останніх досліджень і публікацій. Важливість та актуальність підготовки здобувачів вищої освіти в умовах впровадження компетентнісного підходу, євроінтеграції та забезпечення принципу студентської мобільності підтверджується численними працями відомих науковців. Питання побудови освітніх програм різних спеціальностей на основі компетентнісного підходу відтворені у працях В. Андрущенка, В. Захарченка, В. Лугового, Ю. Рашкевича, Ж. Таланова та інших вчених. А. Заслужена, О. Ковальчук та Г. П’ятакова досліджувалися питання підготовки магістрів гуманітарних спеціальностей в Україні, Польщі, Швейцарській Конфедерації. Водночас, аналізу навчальних планів підготовки магістрів гуманітарного напрямку, зокрема майбутніх учителів української мови і літератури, приділено недостатньо уваги.

Мета статті. Аналіз навчального плану підготовки здобувачів вищої освіти другого (магістерського) рівня спеціальності 014.01 Середня освіта. Українська мова і література.

Виклад основного матеріалу. Сьогодні розвиток освіти відбувається під впливом різноманітних суспільних інтеграційних процесів та принципів, таких як:

- інформатизації та глобалізації суспільства;

- зорієнтованість освіти на особистість студентів та їх різнобічний розвиток;
- забезпечення студентської мобільності;

- упровадження компетентнісного підходу у підготовку майбутніх фахівців з урахуванням Національної рамки кваліфікацій;

- підвищення конкурентоспроможності фахівця.

Зазначені процеси відбуваються на тлі інтеграції нашої держави до європейського освітнього простору $[6,5]$, що робить їх важливими з точки зору відповідності сучасним тенденціям у всьому світі. Більшість 3 цих підходів визначено у Національній стратегії розвитку освіти в Україні на період до 2021 року у якості стратегічних напрямів розвитку освіти та основних завдань даного законодавчого документу [7].

Одним із найвищих рівнів підготовки здобувачів вищої освіти вважається другий (магістерський) рівень. В ст. 5 Закону України про вищу освіту дається таке визначення: "Магістр це освітній ступінь, що здобувається на другому рівні вищої освіти та присуджується вищим навчальним закладом (науковою установою) у результаті успішного виконання здобувачем вищої освіти відповідної освітньої програми [3]. Магістратуру можна вважати сполучною ланкою між вузівським освітою і аспірантурою, що забезпечує підготовку наукових і педагогічних кадрів, ланкою, що допомагає виявити здібності магістранта до науково-дослідної роботи і таким чином, визначити подальший напрямок його діяльності.

У нашому дослідженні ми орієнтуємося на підготовку підготовки здобувачів вищої освіти другого (магістерського) рівня спеціальності 014.01 Середня освіта. Українська мова і література за освітньою програмою, яка має назву "Середня освіта. Українська мова і література. Англійська мова і література, галузі знань 01 Освіта/Педагогіка". Здобувачі можуть вступати на другий (магістерський) рівень на основі освітнього ступеня "Бакалавр" або освітньокваліфікаційного рівня “Спеціаліст”. Ступінь магістра здобувається за освітньо-професійною програмою, обсяг якої становить 90 кредитів ЄКTC.

Після завершення магістерського рівня за освітньою програмою "Середня освіта. Українська мова і література. Англійська мова i література, галузь знань 01 Освіта/Педагогіка" здобувач отримує таку академічну кваліфікацію: “магістр середньої освіти (за предметною 


\section{АНАЛІЗ НАВЧАЛЬНОГО ПЛАНУ ПІДГОТОВКИ ЗДОБУВАЧІВ ВИЩОЇ ОСВІТИ ДРУГОГО (МАГІСТЕРСЬКОГО) РІВНЯГУМАНІТАРНОГО НАПРЯМКУ}

спеціальністю “Українська мова і
література")".
Професійна кваліфікація буде вказана так: “вчитель української мови ілітератури, англійської мови та зарубіжної літератури”. Кваліфікація у дипломі: "Магістр середньої освіти (за предметною спеціальністю "Українська мова i література"). Вчитель української мови і літератури англійської мови та зарубіжної літератури". У Мелітопольському державному педагогічному університеті $є$ магістратура на денній та заочній формах навчання, яка триває протягом 1 року і 4 місяців.

Придатність до працевлаштування: Випускників програми призначено для викладацької, навчально-виховної, науковометодичної та організаційно-управлінської діяльності в системі освіти України відповідно до отриманого напряму підготовки. Магістр філології здатний проводити самостійні науково-критичні дослідження як на замовлення зацікавлених в цьому інституцій (міністерств, відомств, комітетів, фондів, видавництв, редакцій тощо), так і в аспекті власного становлення як фахівця.

Вчитель української мови та літератури, англійської мови та зарубіжної літератури в закладах середньої освіти, зокрема у старшій (профільній) школі, інспектор-методист, педагогорганізатор, працівник в інституціях культурнопросвітницького спрямування, у сфері реклами, референт, адміністративний помічник, секретар керівника (організації, підприємства, установи), копірайтер, контент-менеджер, офіс-менеджер, помічник проектного менеджера, координатор проектів, стажист-дослідник, викладач-стажист.

Ми згодні з думкою С. Вітвицької, яка визначає педагогічну освіту магістрів у вигляді багатофункціонального та відкритого циклу педагогічної освіти, який реалізується через складні організаційні та змістово-процесуальні зв'язки, має специфічну мету, функції, форми та методи $[1,70]$. Нормативну основу підготовки майбутнього фахівця складають освітньокваліфікаційна характеристика, яка пов'язує професійну та навчально-пізнавальну діяльність здобувачів вищої освіти, навчальний план, перелік нормативних навчальних дисциплін. Послідовність опанування навчальними дисциплінами, поточний та підсумковий контроль визначаються структурно-логічною схемою підготовки, яка відображена в освітній програми спеціальності [8, 152]. В свою чергу, зміст навчання, його методи, форми і засоби повинні бути акцентовані на використанні інноваційних тенденцій у вищій педагогічній освіті. До основних форм організації навчання магістрів Г. П’ятакова відносить лекції, практичні, семінарські заняття, самостійну навчальну діяльність студентів [9, 157].

Підготовка вчителя української мови i літератури, англійської мови та зарубіжної літератури в умовах закладу вищої освіти повинна передбачати опанування здобувачами вищої освіти низки базових дисциплін із циклу загальної підготовки (ОЗП), таких як цивільний захист, менеджмент і маркетинг в освіті, методи та засоби комп'ютерних інформаційних технологій, філософія освіти, іноземна мова для академічного спілкування. Усі заявлені дисципліни розраховані по 90 год/3 кредити.

У цілому, процес навчання в магістратурі має бути спрямованим на формування в студентів загальнокультурних і професійних компетенцій, передбачених освітніми стандартами. Такий розподіл компетентностей цілком відповідає рекомендаціям проекту Тюнінг, у межах якого розглядаються загальні компетентності, які мають універсальний характер та спеціальні (фахові) компетентності, які визначають кваліфікацію випускника та профіль освітньої програми [10,32].

Навчаюсь в магістратурі, здобувач вищої освіти опановує здатністю усвідомлено засвоювати знання з дисциплін, передбачених навчальним планом - самостійно і під керівництвом викладача; застосовувати отримані знання у практичній роботі; бути комунікативним, ініціативним, відповідальним, працювати в колективі; обирати творчий підхід до процесу навчання і викладання. Також він накопичує здатність до письмової й усної комунікації державною та іноземною мовами; володіти комп'ютером на рівні користувача, виявляти елементарні навички медіа грамотності, розвиває уміння визначити коло своїх обов'язків за напрямом професійної діяльності.

Вивчаючи дисципліни циклу загальної підготовки здобувачі вищої освіти можуть опановувати і фахові компетентності, зокрема здатність до письмової й усної комунікації іноземною мовою; здатність сформувати іншомовну мовленнєву та мовну компетентності учнів; здатність знаходити, використовувати навчальну й наукову інформацію, у тому числі іншомовну, в галузі філології та методики викладання на паперових та електронних носіях; уміння вибудовувати прогностичні сценарії та моделі розвитку комунікативних і соціокультурних ситуацій; здатність вивчати об'єкти і предмети 3 погляду аналізу соціально-антропологічних, соціоекономічних і культурно-історичних умов їх 
походження; здатність застосовувати операції логічного мислення для побудови власних англомовних висловлювань; здатність розуміти сприйняте на слух усне мовлення і реагувати на нього, здатність розуміти інструкції, повідомлення в академічному та професійному середовищах; здатність розуміти намір мовця і комунікативні наслідки його висловлювання; здатність розуміти основні ідеї та розпізнавати відповідну інформацію в ході обговорень, бесід, дебатів, що за темою пов'язані з навчанням та спеціальністю; здатність виступати 3 підготовленими індивідуальними презентаціями щодо професійного кола тем.

Навчання за циклом загальної підготовки передбачає отримання результатів: здобувачі вищої школи отримують знання методів філологічних досліджень, основних напрямків розвитку філологічної науки; глибокі знання фундаментальних наук, в обсязі, необхідному для освоєння загальнопрофесійних дисциплін; основних тенденцій методики викладання англійської мови у закладах середньої освіти на старших етапах; шляхів розвитку і сучасного стану англійської мови із визначенням актуальних проблем мовознавства; правових та етичних норм, які регулюють відносини між людьми в професійних колективах. Також магістри отримують уміння та навички з предметної області, практичні навички у напрямку уміння використовувати новітні освітні технології, створювати презентації, буклети, блоги; порівнювати лексичні одиниці, властиві американському та британському варіантам англійської мови та українській мові; надавати правильну теоретичну інтерпретацію літературним явищам; виявити структурні варіанти, подібні за значенням, у розглянутих варіантах; вміти використовувати різні діалекти у мовленні тощо.

Цикл професійної підготовки (ОПП) здобувачів другого (магістерського) рівня передбачає такі дисципліни: охорона праці, гендерна педагогіка, загальне мовознавство, теорія літератури, методика вивчення української мови на старшому етапі в закладах середньої освіти, методика вивчення української і зарубіжної літератури на старшому етапі в закладах середньої освіти, історія української літературної мови, актуальні проблеми морфології і синтаксису, актуальні проблеми української літератури, актуальні проблеми зарубіжної літератури. До цього циклу також додається виробнича практика (педагогічна), яка триває шість тижнів та підготовка до захистута захист дипломної роботи. Усього за циклом професійної підготовки передбачено навчальним планом 1560 год./52 кредити. Компетентності та результати навчання до кожної дисциплін представлені в освітньопрофесійній програмі, яка затверджується у закладах вищої освіти одночасно із затвердженням навчального плану.

Цикл дисциплін професійної підготовки (ВПП) за вільним вибором студента містить наступні дисципліни: Перелік 1. (порівняльна типологія, теоретичний курс іноземної мови), Перелік 2. (міжкультурна комунікація, література англомовних країн), Перелік 3. (теорія і практика перекладу англомовного тексту, методика вивчення англійської мови на старшому етапі в закладах середньої освіти), Перелік 4. (філологічна медіа грамотність, інноваційні обрії української словесності), Перелік 5. (лінгвокультурологія, етнолінгвістика), Перелік 6. (культура англомовного спілкування, практичний курс англійської мови). Усього навчальним планом передбачено за цим циклом 690 год./23 кредити.

Якість підготовки здобувачів вищої освіти до майбутньої професійної діяльності багато в чому залежить від досконало опрацьованих освітньопрофесійних програм, які повинні враховувати сучасні освітні стандарти та нові технології педагогічної науки [5, 204]. Слід зазначити, що розробка якісних програм вищої освіти є цілком закономірним кроком на шляху модернізації змісту вищої освіти та дотримання рекомендації проекту Тюнінг у рамках реформування європейського освітнього простору $[4,6]$.

Успішність реалізації освітніх програм підготовки магістрів в педагогічному університеті залежить від певних умов, а саме:

- високий рівень викладачів, які приймають участь у забезпечення підготовки магістрів;

- наявність засобів моніторингу професійного становлення здобувача вищої освіти;

- науково-методичне та інформаційне забезпечення навчального процесу на рівні використання баз даних, електронних освітніх ресурсів [2, 101];

- спонукання магістрантів до побудови індивідуальної освітньої траєкторії, яка дозволить максимально розвинути потрібні компетентності з урахуванням інтересів студентів у межах обраної ними спеціальності [11, 150].

Якщо проаналізувати освітню програму вищої освіти другого (магістерського) рівня “Середня освіта. Українська мова і література. Англійська мова і література" спеціальності 014.01 Середня освіта (Українська мова і література), то можна виділити перелік компетентностей, якими повинні володіти випускники цієї спеціальності. Так, інтегральна компетентність (вона одна) 


\section{АНАЛІЗ НАВЧАЛЬНОГО ПЛАНУ ПДГОТОВКИЗДОБУВАЧІВ ВИЩОЇ ОСВІТИ ДРУГОГО (МАГІСТЕРСЬКОГО) РІВНЯГУМАНІТАРНОГО НАПРЯМКУ}

передбачає здатність розв'язувати складні спеціалізовані задачі та практичні проблеми у галузі філологічної освіти або у процесі навчання, що передбачає застосування певних теорій та методів мовознавчої та літературознавчої, а також педагогічної наук i характеризується комплексністю та невизначеністю умов.

Навчаючись в магістратурі, здобувачі вищої освіти опановують загальні компетентності (ЗК) (здатність усвідомлено засвоювати знання 3 дисциплін, передбачених навчальним планом самостійно і під керівництвом викладача; застосовувати отримані знання у практичній роботі; бути комунікативним, ініціативним, відповідальним, працювати в колективі; обирати творчий підхід до процесу навчання і викладання; проводити наукову діяльність у галузі філології та педагогіки; знання та розуміння предметної області та розуміння професії; володіти комп'ютером на рівні користувача, виявляти елементарні навички медіа-грамотності; проведення досліджень на відповідному рівні; уміння визначити коло своїх обов'язків за напрямом професійної діяльності з урахуванням завдань з цивільного захисту; прагнення до саморозвитку, підвищення кваліфікації та майстерності тощо.

Фахова компетентність майбутнього вчителя української мови і літератури, англійської мови і зарубіжної літератури включає в себе здатність володіти методологічними і теоретичними основами філологічних наук; володіти методологічними і теоретичними основами філологічних наук, методик навчання англійської мови та зарубіжної літератури, базовими знаннями 3 англійської мови, теорії та історії іноземної мови й літератури, методики викладання англійської мови; використовувати науковий апарат для засвоєння теоретичних основ української мови і літератури, методик їх викладання у старших (профільних) класах; знаходити, використовувати навчальну й наукову інформацію, у тому числі іншомовну, в галузі філології та методики викладання на паперових та електронних носіях; орієнтуватись в сучасних тенденціях розвитку українського письменства, розуміти філософськоестетичні основи літературної творчості, особливості літературно-художньої епохи, вияви національно-художньої та особистісно-творчої самоідентифікації сучасних українських письменників, визначати і вирішувати основні проблеми на шляху розвитку літературного процесу України.

Нормативний зміст підготовки магістрів спеціальності 014.01 Середня освіта. Українська мова і література сформульований у термінах результатів навчання, яких освітня програма зазначеної спеціальності налічує 22 результатів навчання (уміння проводити експерименти в галузі англійської мови, лінгводидактики та навчання зарубіжної літератури; упорядковувати отримані теоретичні та практичні дані щодо дослідження в мові та літературі; аргументувати власні судження, класифікувати мовні та мовленнєві феномени; оцінювати особистий інтелектуальний та професійний рівень; виділяти і обгрунтовувати періоди розвитку української літературної мови, орієнтуючись на мовні особливості пам'яток та історичні дані про український етнос; простежувати історичний взаємозв'язок діалектної та літературної форм української мови; визначати критерії літературності мови; 3'ясовувати стилістичну і жанрову специфіку цих творів; виявляти риси простої, книжної і старослов'янської мов у пам'ятках різних стилів і жанрів; встановлювати за мовностилістичними особливостями історичну специфіку жанру чи стилю, оцінюючи внесок окремих персоналій в історію української літературної мови; зіставляючи мовні факти тощо).

Також в освітній програмі вищої освіти другого (магістерського) рівня наведені всі навчальні дисципліни, які $€$ в навчальному плані спеціальності, у відповідності до програмних компетентностей та результатів навчання. Атестація випускників освітньої програми “Середня освіта. Українська мова і література. Англійська мова і література" спеціальності 014.01 Середня освіта (Українська мова i література) проводиться у формі захисту кваліфікаційної магістерської роботи та комплексного державного екзамену з англійської мови та зарубіжної літератури.

Висновки. Отже, підготовка магістра вчителя української мови і літератури, англійської мови і зарубіжної літератури спеціальності 014.01 Середня освіта. Українська мова і література заснована на ряді нормативних документів спеціальності, а саме освітньому профілі спеціальності, освітній програмі спеціальності, навчальному плані спеціальності. Єдність цих документів дозволяє організувати послідовний та систематизований навчальний процес, який надасть можливість підготовити сучасних та мобільних здобувачів вищої освіти із актуальним переліком фахових та загальних компетентностей. У подальшій роботи планується проаналізувати освітню програму підготовки бакалаврів спеціальності 014.01 Середня освіта. Українська мова і література. 


\section{АНАЛІЗ НАВЧАЛЬНОГО ПЛАНУ ПДГОТОВКИЗДОБУВАЧІВ ВИЩОЇ ОСВІТИ ДРУГОГО (МАГІСТЕРСЬКОГО) РІВНЯ ГУМАНІТАРНОГО НАПРЯМКУ}

\begin{tabular}{l}
\hline ЛІТЕРАТУРА \\
1. Вітвицька С.С. Теоретичні засади підготовки \\
магістрів в умовах ступеневої педагогічної освіти. \\
Вісник Житомирського державного університету імені \\
Івана Франка. 2004. №19. С. 69 - 71. \\
2. Гуревич Р.С. Інноваційні педагогічні технології в \\
підготовці магістрів. Теорія і практика управління \\
соціальними системами. 2013. №2. С. 100-105. \\
3. Закон України “Про вищу освіту” із змінами, \\
внесеними згідно із Законами. URL: http:// \\
zakon.rada.gov.ua/laws/show/1556-18.
\end{tabular}

4. Захарченко В.М., Луговий, В.І., Рашкевич, Ю.М., Таланова Ж.В. Розроблення освітніх програм. Методичні рекомендації / За ред. В.Г. Кременя. Київ, 2014. $120 \mathrm{c}$.

5. Ковальчук О.М. Проблеми підготовки магістрів гуманітарних спеціальностей до інноваційної діяльності в умовах ступеневої освіти. Педагогічні науки: теорія, історія, інноваційні технології. 2013. №6(32). С. 201-207.

6. Компетентнісний підхід у сучасній освіті: світовий досвід та українські перспективи: Бібліотека з освітньої політики / Під заг. ред. О.В. Овчарук. К.. “К.І.С.”, 2004. $112 \mathrm{c}$.

7. Національна стратегія розвитку освіти в Україні на період до 2021 року. URL: https://zakon.rada.gov.ua/ laws/show/344/2013.

8. Осипова Н.В., Вінник, М.О., Тарасіч Ю.Г. Модель формування дослідницької компетентності у майбугніх інженерів-програмістів. Information Technologies in Education. 2014. №20. C. $150-159$.

9. П'ятакова Г. Особливості підготовки магістрів за спеціальністю Українська філологія у Львівському та Вроцлавському університетах. Вісник Львівського університету. Серія: Педагогічна. 2011. №27. С. 155 162.

10. Рашкевич Ю.М. Болонський процес та нова парадигма вищої освіти: монографія. Львів: Видавництво Львівської політехніки, 2014. 168 с.

11. Шаров С. В., Шарова Т.М. Формування індивідуальної освітньої траєкторії студента засобами інформаційної системи. Науковий вісник Мелітопольського державного педагогічного університету імені Богдана Хмельницького. Серія: Педагогіка. 2017. Т.2. №19. С. 149 - 154.

\section{REFERENCES}

1. Vitvytska, S.S. (2004). Teoretychni zasady pidhotovky mahistriv $\mathrm{v}$ umovakh stupenevoi pedahohichnoi osvity [Theoretical principles of preparation of masters in the conditions of advanced pedagogical education]. Bulletin of Zhytomyr State University named after Ivan Franko, No. 19, pp. 69 - 71. [in Ukrainian].

2. Hurevych, R.S. (2013). Innovatsiini pedahohichni tekhnolohii $\mathrm{v}$ pidhotovtsi mahistriv [Innovative pedagogical technologies in the preparation of masters].
The theory and practice of social systems management, No.2, pp. 100 - 105. [in Ukrainian].

3. Zakon Ukrainy "Pro vyshchu osvitu" iz zminamy, vnesenymy zghidno iz Zakonamy [The Law of Ukraine "On Higher Education", as amended in accordance with the Laws]. Available at: http://zakon.rada.gov.ua/laws/ show/1556-18. [in Ukrainian].

4. Zakharchenko, V.M., Luhovyi, V.I., Rashkevych, Yu.M. \& Talanova, Zh.V. (2014). Rozroblennia osvitnikh prohram. Metodychni rekomendatsii [Development of educational programs. Guidelines]. Kyiv, 120 p. [in Ukrainian].

5. Kovalchuk, O.M. (2013). Problemy pidhotovky mahistriv humanitarnykh spetsialnostei do innovatsiinoi diialnosti v umovakh stupenevoi osvity [Problems of preparing masters of humanitarian specialties for innovative activity in conditions of graduate education]. Pedagogical sciences: theory, history, innovative technologies, No.6(32), pp. 201 -207. [in Ukrainian].

6. Ovcharuk, O.V. (2004). Kompetentnisnyi pidkhid u suchasnii osviti: svitovyi dosvid ta ukrainski perspektyvy: Biblioteka z osvitnoi polityky [Competency approach in modern education: world experience and Ukrainian perspectives: Library for educational policy]. Kyiv: “K.I.S.”, 112 p. [in Ukrainian].

7. Natsionalna stratehiia rozvytku osvity v Ukraini na period do 2021 roku [The National Strategy for the Development of Education in Ukraine until 2021]. Available at: https://zakon.rada.gov.ua/laws/show/344/2013. [in Ukrainian].

8. Osypova, N.V., Vinnyk, M.O. \& Tarasich, Yu.H. (2014). Model formuvannia doslidnytskoi kompetentnosti u maibutnikh inzheneriv-prohramistiv [Model of research competence development in future engineer programmers]. Information Technologies in Education, No.20, pp. 150 159. [in Ukrainian].

9. Piatakova, H. (2011). Osoblyvosti pidhotovky mahistriv za spetsialnistiu Ukrainska filolohiia u Lvivskomu ta Vrotslavskomu universytetakh [Features of masters training in the specialty Ukrainian Philology at the Lviv and Wroclaw Universities]. Bulletin of Lviv University. Series: Pedagogical, No.27, pp. 155 - 162. [in Ukrainian].

10. Rashkevych, Yu.M. (2014). Bolonskyi protses ta nova paradyhma vyshchoi osvity: monohrafiia [Bologna Process and New Paradigm of Higher Education: Monograph]. Lviv: Lvivskoi politekhniky Publ., 168 p. [in Ukrainian].

11. Sharov, S.V. \& Sharova, T.M. (2017). Formuvannia indyvidualnoi osvitnoi traiektorii studenta zasobamy informatsiinoi systemy [Formation of an individual educational trajectory of a student by means of an information system]. Scientific Bulletin of Melitopol State Pedagogical University named after Bogdan Khmelnitsky. Series: Pedagogy, vol. 2, No.19, pp. $149-$ 154. [in Ukrainian].

Стаття надійшла до редакції 07.02.2019

\section{G580801058080

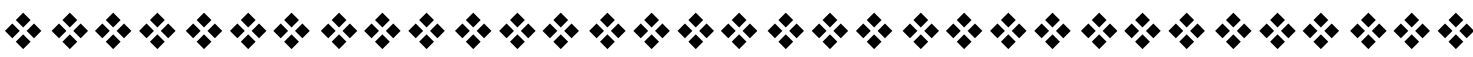

